\title{
PERAN PEREMPUAN DALAM MERUMAH
}

\author{
Koniherawati ${ }^{1}$, Priyo Pratikno ${ }^{2}$ \\ ${ }^{1)}$ Staf pengajar Program Studi Desain Produk, Fakultas Arsitektur dan Desain UKDW \\ ${ }^{2)}$ Staf pengajar Program Studi Arsitektur, Fakultas Arsitektur dan Desain UKDW \\ Email: gentong_koni@yahoo.com, inipriyo@yahoo.co.id
}

\begin{abstract}
Abstrak
Perempuan, dalam hal ini ibu, memiliki peran utama dalam membangun dan memelihara rumah, sebagaimana sejak dulu ditunjukkan oleh berbagai suku bangsa di dunia. Berbagai peran ibu ditunjukkan dalam memberi perlindungan, kenyamanan, dan rasa aman bagi bayinya hingga anggota keluarganya yang telah dewasa. Ibu juga seseorang yang memberikan nuansa bagi rumahnya melalui berbagai kegiatan seperti mengolah makanan hingga cara berhias diri. Upaya mengumpulkan material bangunan, menghias, dan mengisi bermacam perabot rumah tinggal terkait erat dengan aktivitas ibu yang amat dominan itu.

Penelitian ini merupakan upaya menggali permasalahan merancang yang dilakukan para perempuan pada masa lalu yang ditujukan untuk mendapatkan pembenaran pada desain-desain seni dan arsitektur. Penelitian ini berdasarkan studi literatur ini menunjukkan peran ibu dalam membangun, mengelola, dan memaknai sebuah rumah tinggal. Metoda dilakukan dengan mencari data dari sumber sekunder kemudian merangkaikan aspek-aspek yang dapat untuk digunakan membangun asumsi dan hipotesa. Berdasarkan penelusuran terhadap informasi yang diperoleh disimpulkan bahwa perempuan sebagai ibu rumah tangga memiliki peran signifikan dalam membentuk rumah secara budaya maupun secara fisikal. Hasil penelitian menunjukkan bahwa perempuan yang berstatus ibu sangat dominan dalam memberi nuansa dan bentuk pada sebuah rumah.
\end{abstract}

Kata kunci: Dominasi perempuan, fungsi rumah, dan wujud rumah tangga.

\begin{abstract}
Title: The Roles of Wemen in Domestic Activities

Women, especially mother, has a major role in build and maintain a home, as shown by various ethnic groups in the world. The various roles of woman indicated in protection, give a sense of comfort, and safety for the baby and all family member. Mother is person who gives a shade of home through food processing activities and how to primp her self. The efforts collecting building materials, to decorate, and chose home furnishings are dominant activities that mother does.

This study is explore the problems of designing of home by women in the past were intended to justify the design of art and architecture. This study based on literature that shows the role of the mother in build, manage, and interpreting a house. The method of this study base on secondary data and then weave every aspects to build the hypotheses. These information show that women as housewives have a significant role in shaping the house as culturally or physically. The results showed that women as mother very dominant in giving the feel and shape of house.
\end{abstract}

Keywords: Female domination, home function, and character of home.

\section{Pendahuluan}

"Like a shell, the house can open to others, and like a fortress it can protect against them..." (Martin dan Laffon, 2004)

Manusia purba melindungi dirinya dari ancaman binatang buas dan keganasan 
alam dengan tinggal dalam gua. Seorang bayi akan merasa nyaman dan aman dalam dekapan ibunya, dan merasa hangat tubuhnya dalam balutan selendang gendong di dada ibunya. Jadi 'rumah' adalah tempat berlindung yang menyebabkan penghuninya akan merasa nyaman dan aman walau apapun bentuk dan material yang pembentuk tempat perlindungan tersebut. Perihal ini berlaku bagi seluruh mahluk hidup seperti hewan laba-laba yang tinggal dalam rumah perlindungannya yang berupa rajutan benang. Begitu pula dengan seekor ulat yang berumahkan kepompong, ataupun burung dengan sarang yang dirajutnya di tangkai pepohonan. Maka rumah dibangun sebagai perlindungan diri dengan beragam kemungkinan material berdasarkan kebutuhan dan situasi di lingkungan alam yang menyediakan berbagai segala potensi yang ada.

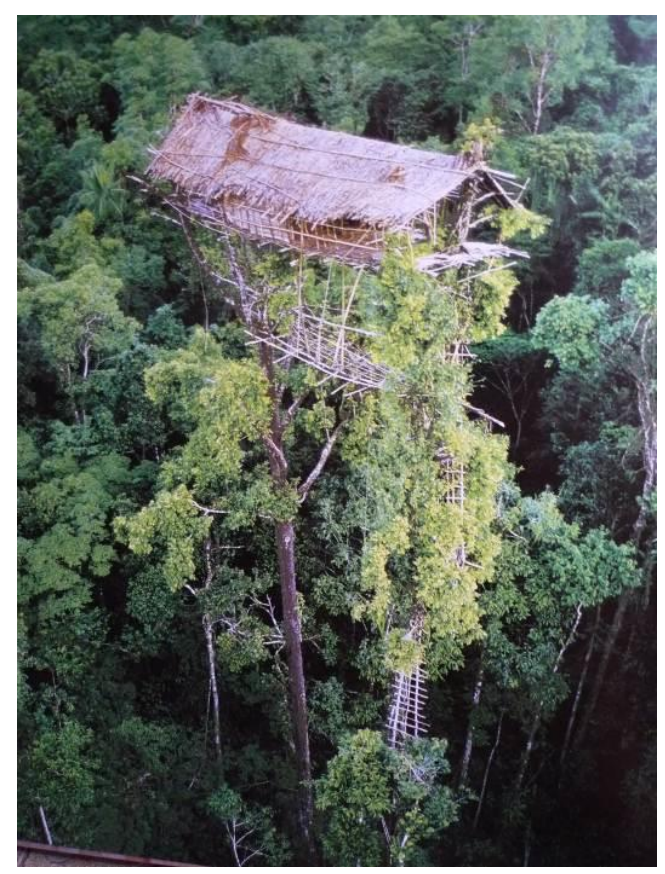

Gambar 1. Di Papua rumah dibangun setinggi pohon diantara hutan lebat untuk menghindari binatang buas Sumber: Laffon, 2004

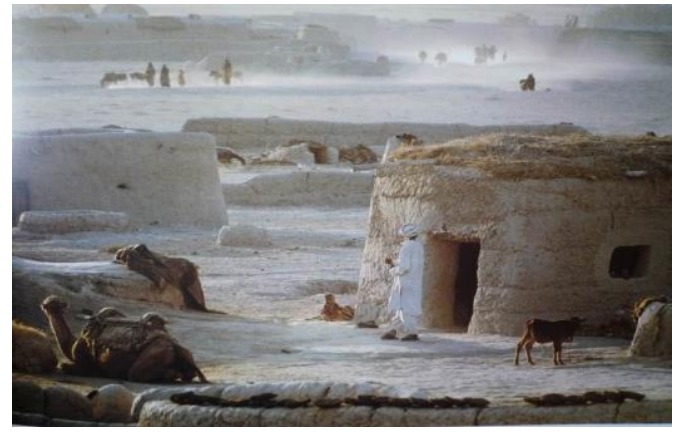

Gambar 2. Di daerah Kunduz, Afganistan, dinding sekeliling rumah dilapisi lumpur, sementara lubang pintu dan jendela kecil untuk melindungi diri dari suhu udara yang dingin dimalam hari

Sumber: Laffon, 2004

Sejak keluarga berumah secara menetap, peran perempuan dalam membentuk atau membangun rumah tinggal amat dominan. Sejarah menunjukkan bahwa membangun rumah selalu diperankan oleh perempuan atau istri. Di Kenya Afrika Selatan dominasi perempuan dalam beberapa aspek lebih besar dibandingkan dengan peran lelaki atau suami. Para perempuan bertugas mengumpulkan kulit binatang untuk dirangkai menjadi sebuah penutup atap yang berupa tenda. Sejak dari kegiatan memasang, menurunkan dan menggulung penutup tenda bangunan dilakukan oleh perempuan.

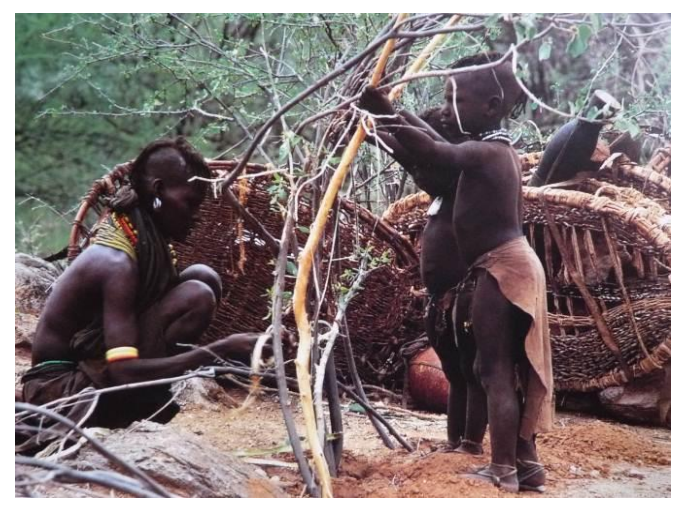

Gambar 3. Di Kamerun suku Pygmy membangun tenda atau rumah sebagai tempat persinggahan dimalam hari dan untuk menyimpan makanan Sumber: Laffon, 2004 
Sebagaimana diketahui penduduk Kenya pada saat itu masih sering berpindah tempat tinggalnya. Rumah menjadi kulit kedua yang memberi kehangatan dan kenyamanan, sebagaimana digambarkan bagaimana fungsi rumah yang seperti seorang perempuan, ibu, dalam memberikan perlindungan pada insan yang rapuh yakni bayi yang masih lemah.

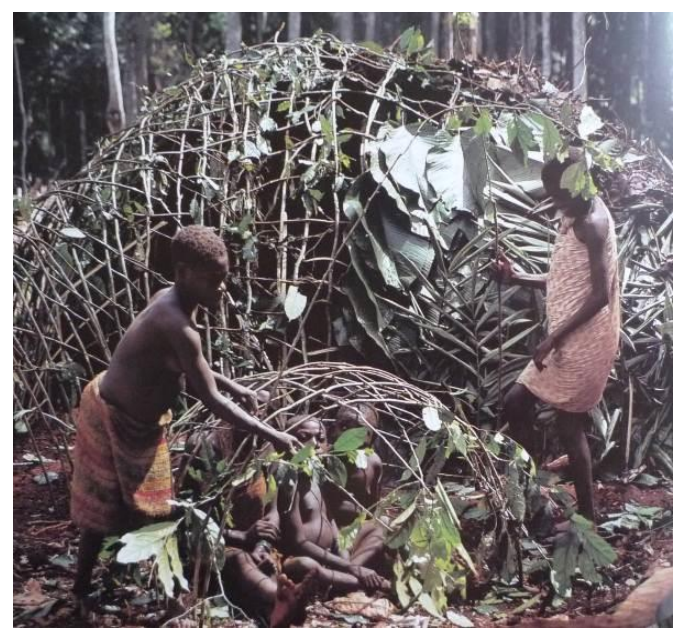

Gambar 4. Suku Turkana di Kenya, Afrika, menyiapkan tenda dikerjakan oleh perempuan dengan cepat dalam waktu yang singkat

Sumber: Laffon, 2004

\section{Tujuan dan Manfaat Penelitian}

\section{Tujuan Penelitian}

Tujuan penelitian ini berupaya memahami peran perempuan dalam membangun rumah dan rumah tangga. Menguak peran perempuan dalam menentukan wujud arsitektur rumah tinggalnya juga dalam hal memberikan warna pada budaya merumah termasuk perilaku anggota keluarga. Informasi hasil penelitian ini mempertegas pembentukan ruang dalam bangunan berdasarkan jender.

\section{Manfaat Penelitian}

Penelitian ini membantu para arsitek dalam berkonsep dan merancang rumah tinggal terutama dalam menentukan berbagai ornamen, hingga rancangan perabot rumah. Bagi perkembangan studi tentang jender, penelitian ini memperkuat pendapat bahwa perempuan merupakan aktor utama dalam membentuk suasana dan karakter rumah tangga melalui ketrampilan mengolah potensi alamnya.

\section{Ruang Lingkup Penelitian}

Lingkup penelitian ini membahas masalah jender dalam hubungannya dengan pembentukan rumah tinggal. Ketrampilan para perempuan dalam menggunakan elemen-elemen alami untuk membuat rumahnya melalui ketrampilan merajut, menganyam dan menjalin. Perkembangan sejarah rumah tinggal diberbagai wilayah terkait dengan peran perempuan dalam partisipasinya mengupayakan, membangun, dan memelihara rumahnya, menjadi contoh menajamkan proses kreatif seorang perancang.

\section{Studi Pustaka}

Menurut Laffon (2004), rumah tinggal dibangun sebagai bagian dari strategi manusia melindungi dirinya dari ancaman binatang buas dan keganasan alam. Lebih detil lagi disebutkan bahwa bagi seorang bayi dekapan ibunya, dan merasakan kehangatan tubuh ibunya merupakan tempat berlindung yang menyebabkan merasa nyaman dan aman. Apapun bentuk dan materialnya hal ini merupakan gagasan dasar yang berlaku bagi seluruh mahluk hidup tidak terbatas manusia saja.

Bagi Hannah (2002), rumah yang melindungi itu dihasilkan dari metoda yang unik seperti merajut, menganyam, 
adalah bagian dari tektonika pembuatan sambungan komponen arsitektur yang harus ada dan terjamin pada kekuatannya juga pada keselarasannya.

Mengacu pendapat keduanya baju, rumah dan perlindungan masyarakat manusia akan menghadirkan keterpesonaan baik secara natural maupun kultural membenamkan kita pada suasana hal indah itu. Dalam menghayati karya arsitektur rumah tinggal hingga baju yang dipakai selalu berujung pada bagaimana cara terbentuknya stabilitas keseutuhan (unity), komposisi yang lengkap (completly) sesuai dengan kehendak dan cara pandang yang memakainya.

Teknis pembuatan kain menjadi baju dan penyusunan elemen bangunan menjadi rumah tinggal tersebut memberi kemungkinan bagi pengembangan rancangan untuk kebutuhan masa kini. Pendapat Hannah kini berkembang melalui teknik konstruksi yang lebih efisien serta tidak lagi terbatas pada ketrampilan tangan. Sedangkan Laffon memberi kemungkinan baru bahwa cara melindungi diri tidak lagi tergantung pada hal-hal yang lebih bersifat fisikal tetapi juga yang bersifat transenden.

\section{Prosedur dan Rancangan Penelitian}

Penelitian ini merupakan penelitian terapan yang akan digunakan untuk mendesain karya tentang pelindung fisik seperti halnya baju hingga rumah tinggal. Berdasarkan kebiasaan masyarakat dimasa lalu dalam membuat pelindung fisik yaitu baju dan rumah, yang ternyata didalamnya peran wanita sangat dominan, yang dari kasus tersebut diperoleh konsep desain maupun teknik penyusunan elemen dan bahan dasarnya. Terdapat kesamaan dalam pembuatan baju sebagai pelindung fisik individual, dan konstruksi rumah sebagai pelindung keluarga, yakni selain urusan ketrampilan dan talenta masyarakatnya juga harus memberikan kepuasan secara lahiriah dan batiniah bagi penggunanya.

Cara pembuatan alat perlindungan tersebut secara teknis masih dilakukan oleh masyarakat masa kini. Tektonika arsitektur sebagai upaya mewujudkan bangunan memiliki kesamaan dengan upaya mewujudkan kain hingga baju. Konsep pembuatan baju dan rumah dimasa lalu membuka peluang dalam merancang pelindung diri dan rumah serta menjadi inspirasi bahwa rancangan masa datang akan tetap melanjutkan prinsip perancangan yang selalu melibatkan ketrampilan tangan. Hal tersebut juga terjadi pada metode pembuatan kain sebagai bahan dasar baju. Berdasarkan pemikiran sebagaimana di atas, pengembangan prinsip tektonika dan konsep desain tersebut pada akhirnya dapat digunakan untuk rancangan instalasi baju sebagaimana fungsinya yang melindungi.

\section{Metode Penelitian}

Berdasarkan tujuan yang diharapkan, maka rancangan penelitian yang digunakan berupa penelitian yang bersifat diskriptif kualitatif. Penelitian ini mendeskripsikan kondisi dan karakteristik yang ada diberbagai tempat sebagaimana ditunjukkan dari literatur yang ada. Metode ini dipakai untuk penelitian kali ini yang mengkaji proses pembentukan alat pelindung, termasuk rumah tinggal, sebagai perwujudan dari upaya mengembangan desain berdasarkan preseden dimasa lalu. 


\section{Metode Pengumpulan Data}

Observasi lapangan terhadap aktivitas perempuan masa kini dalam membuat karya seni yang berkaitan dengan dekorasi dan pengadaan elemen interior rumah tinggal. Teknik pengumpulan data yang dilakukan dengan cara melakukan survey langsung guna mendapatkan data-data yang terkait dengan penelitian ini.

Studi Literatur berupa teknik pengumpulan data yang dilakukan dengan cara mengumpulkan referensi atau sumber bacaan serta melakukan pengkajian teori khususnya terkait dengan aspek dan aktivitas pembentuk rumah.

\section{Metode Analisis Data}

Dalam tahapan analisis ini, dilakukan dengan cara melakukan perbandingan antara teori-teori yang ada dengan kondisi lapangan dalam hal ini penggumpulan data-data terkait, sehingga diharapkan dapat menghasilkan suatu konsep tentang peran perempuan dalam konteks jender dengan rumah tinggal.

\section{Hasil dan Pembahasan}

\section{Perempuan}

"The house is personified feminized taking on the form of a primordial belly and cradle of life-or it echoes the cavity of the tomb..."

Rumah sebagai tempat berlindung sering diibaratkan seperti seorang ibu, perempuan, yang memberi kehangatan pada bayi anak-anaknya. Di beberapa kelompok budaya atau daerah, perempuan digambarkan sebagai nyonya-ratu dapur. Yakni tempat untuk seluruh anggota keluarga membutuhkan dirinya lebih dari sekadar untuk urusan makan. Bahkan di India, dapur dianggap sebagai tempat suci.

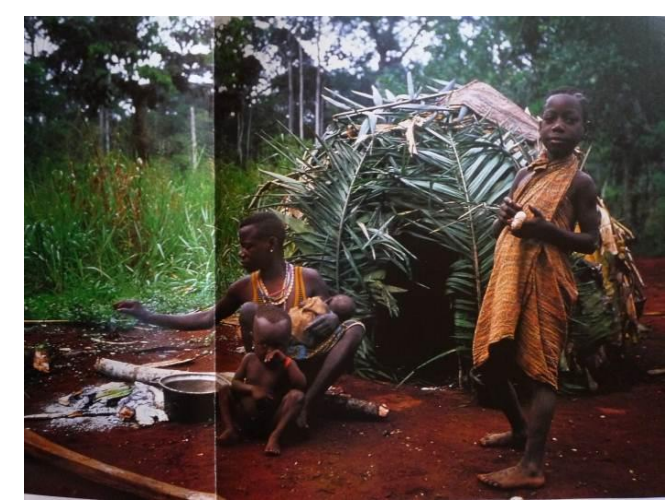

Gambar 5. Di tengah hutan Afrika api merupakan rahasia untuk bertahan hidup bagi suku Pygmy

Sumber: Hannah, 2002

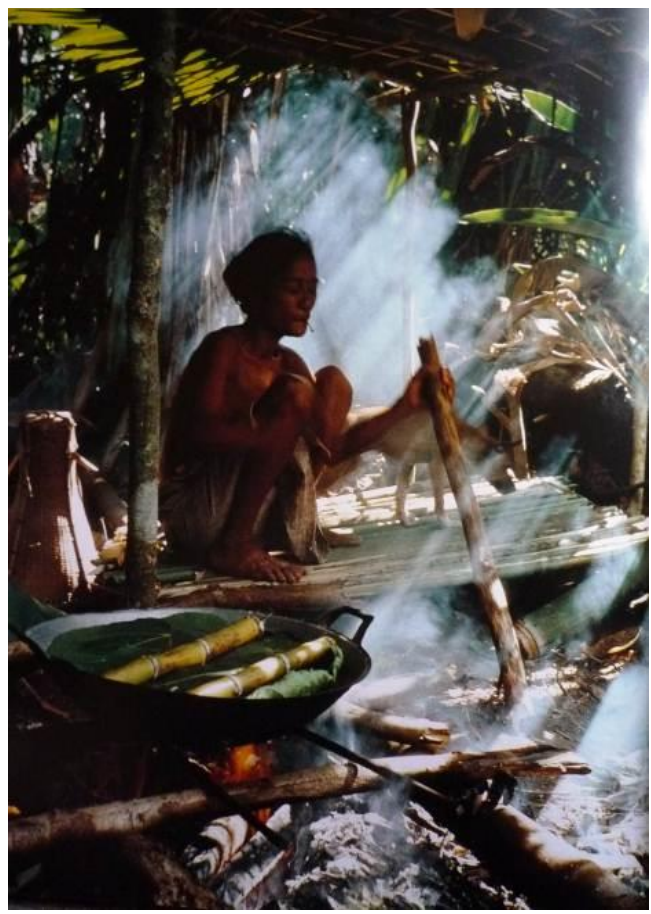

Gambar 6. Para perempuan suku Mafuru di Maluku menyiapkan makanan di bawah atap di luar rumahnya

Sumber: Laffon, 2004

Sementara itu orang-orang suku Pygmy menganggap perempuan sebagai 'men of fire'. Sebegitu pentingnya api yang sangat dibutuhkan oleh semua orang untuk mengusir kegelapan di lebatnya hutan tempat mereka berhuni. Dari api 
pula mereka merasa aman dari serangan gajah liar yang sering mengganggu di perkampungan penduduk. Tak pelak pula api akan memberikan rasa hangat, secara fisikal, di dalam tenda menjelang malam tiba. Di Siberia api juga menjadi ruh, spirit, kehidupan yang tidak pernah pergi dari dalam tubuh manusia. Maka api selalu dijaga agar tetap menyala tak pernah padam.

\section{Menghias}

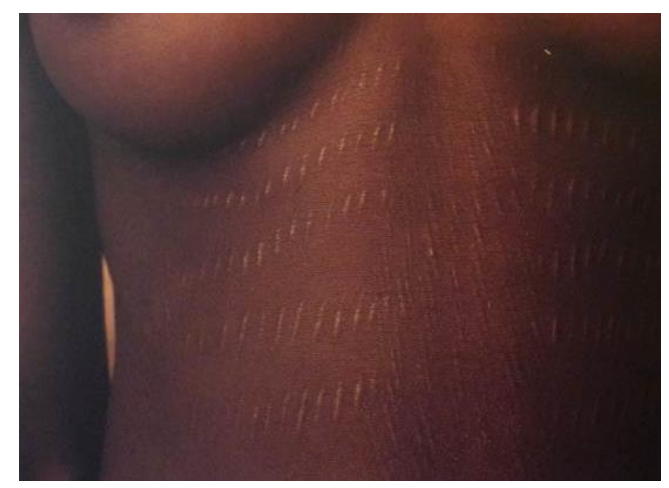

Gambar 7. Perempuan Tamberna, Togo, membuat tatto pada tubuh perempuan terutama yang masih muda sebagai media ungkapan simbolik melalui hiasan yang bermotif etnik

Sumber: Hannah, 2002

Naluri menghias yang dilakukan para perempuan tersebut merambah ke wilayah yang lebih pribadi seperti merajah tubuhnya. Di wilayah Togo Utara di benua Afrika penduduk Tamberna membuat hiasan rumah sebagai simbol yang berhubungan sangat erat dengan bumi, yakni tempat asal usul manusia. Bumi digambarkan sebagai asal-usul kelahirannya yaitu rahim ibu. Lahir dari rahim ibu, yang sebelumnya telah dipelihara di dalam kandungan selama si ibu hamil, kemudian setelah lahir dirawat dan dilindungi ibu. Torehan tekstur pada dinding rumah adalah penangkapan visual terhadap wajah dan tubuh perempuan yang dicetak pada dinding bangunan. Lubang-lubang udara yang kecil itu menyerupai kedua mata sedangkan pintu rumah menggambarkan mulutnya.

Maka tanpa disadari berhias yang dilakukan oleh para perempuan adalah sebuah proses mencipta pada tradisi dimasa lalu. Perempuan juga melakukan kegiatan menghias, atau tepatnya mendekorasi, rumahnya sebagaimana yang dilakukan oleh banyak suku bangsa di belahan dunia. Beberapa contoh dapat dilihat di gambar di bawah ini.

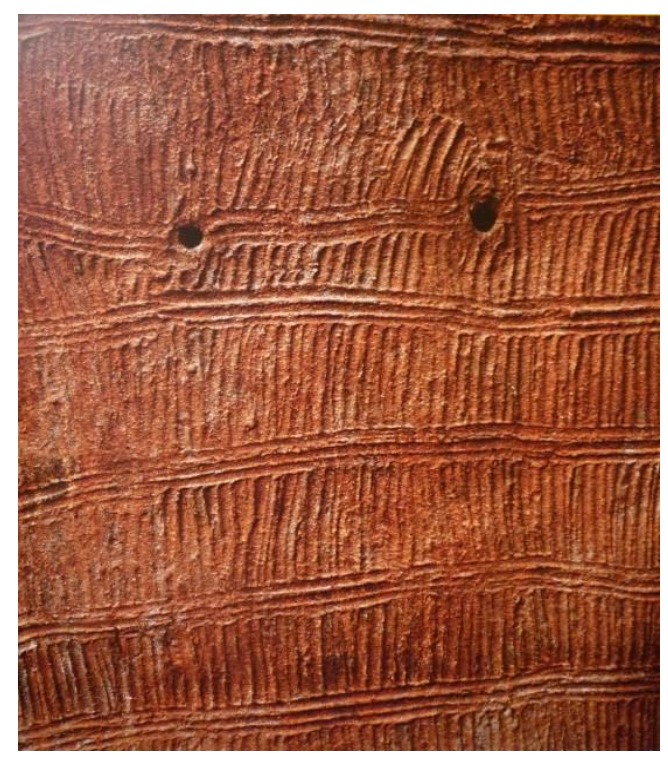

Gambar 8. Motif tekstur tampilan dinding rumah menggunakan sintak tubuh manusia Sumber: Hannah, 2002

\section{Bahan Bangunan}

Ketika membangun, dan khususnya pada tahap menghiasi rumah, orang selalu didorong untuk melakukan dialog dengan lingkungannya. Sebagai contoh pada saat memilih materialnya selalu akan mencari bahan dasar dari potensi yang ada di lingkungannya. Menggunakan bahan, kemudian merespon kebutuhannya selalu dikompromikan dengan potensi alam sekitarnya. Demikian pula pendekatan yang dilakukan dalam menentukan 
teknologi selalu mengupayakan untuk mengembangkan apa yang sudah ada. Bahkan pada suku yang sering berpindah, nomad, untuk membangun tenda atau rumahnya akan selalu bergantung pada potensi alam yang ditemuinya.

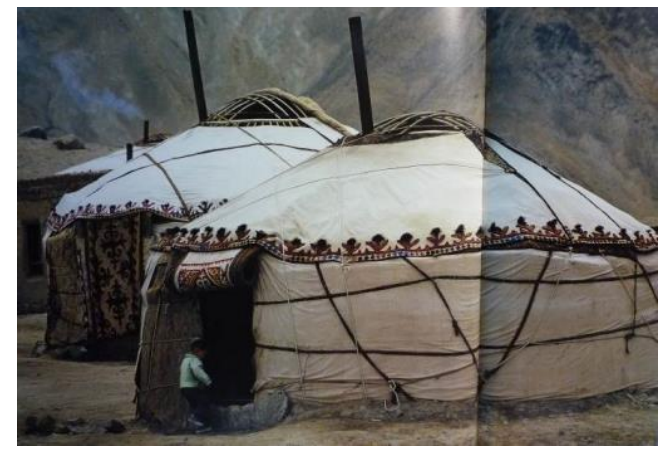

Gambar 9. Tenda suku bangsa Kirghiz, di wilayah danau Karakol, Tiongkok, menggunakan warna putih untuk meneguhkan simbol akan datangnya kekayaan atau kemakmuran

Sumber: Sumber: Hannah, 2002

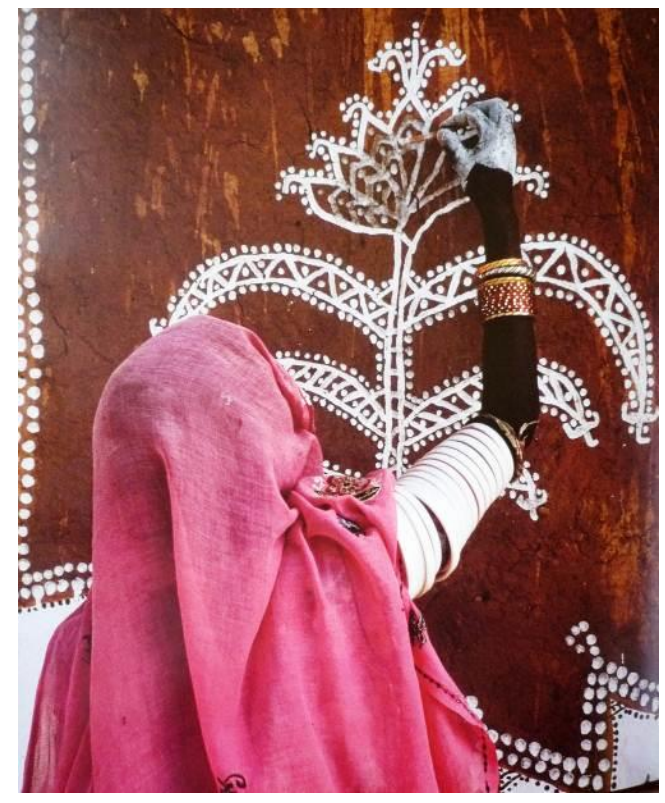

Gambar 10. Desain flora orang-orang TharDesert, India, menggambarkan tetumbuhan dengan pasta yang bahannya tepung beras Sumber: Hannah, 2002

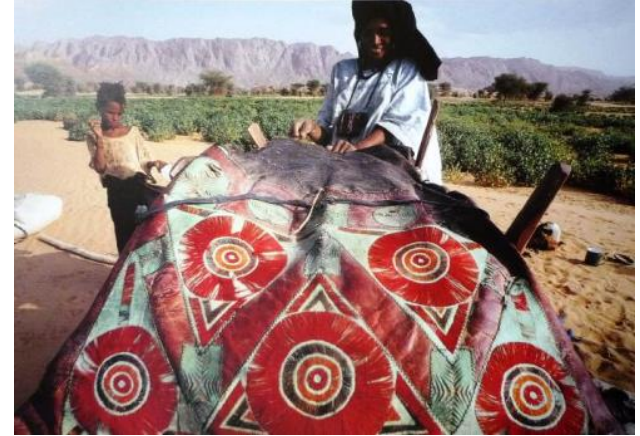

Gambar 11. Kebiasaan orang Nigeria membuat tenda dari kulit binatang dengan dihiasi dengan gambar warna-warni bermotif geometri Sumber: Hannah, 2002

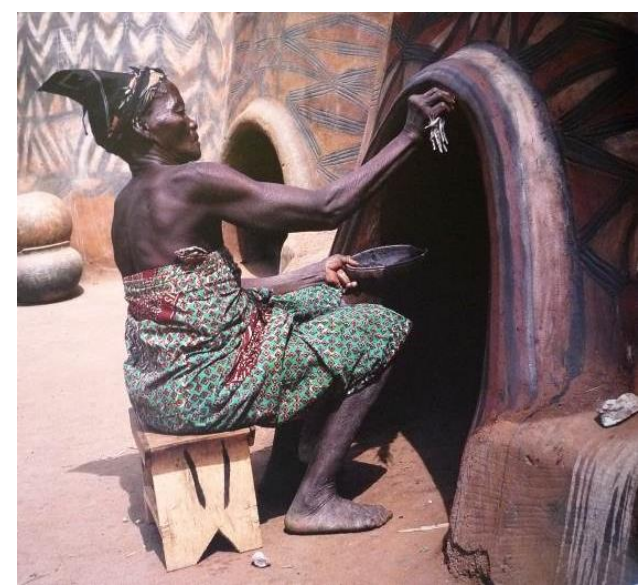

Gambar 12. Di Afrika Barat menghias rumah sebagai kegiatan yang dilakukan oleh para perempuan

Sumber: Hannah, 2002

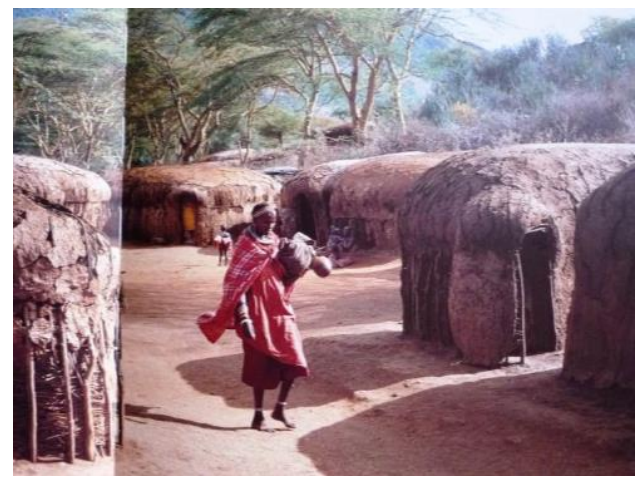

Gambar 13. Rumah orang Massai, Kenya. Membangun rumah merupakan kegiatan para wanita. Menggunakan tiang kayu dan ranting pohon untuk rangka strukturalnya kemudian di atasnya dilapisi tanah liat yang dicampur kotoran hewan terutama kerbau Sumber: Hannah, 2002 


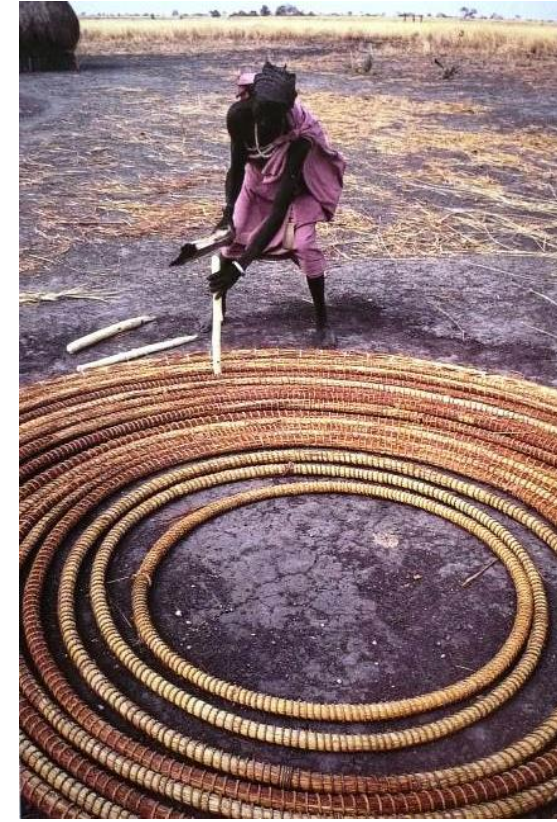

Gambar 14. Orang-orang Shilluck, Sudan Selatan, merangkai ilalang berbentuk lingkaran untuk rangka bangunan tendanya Sumber: Hannah, 2002

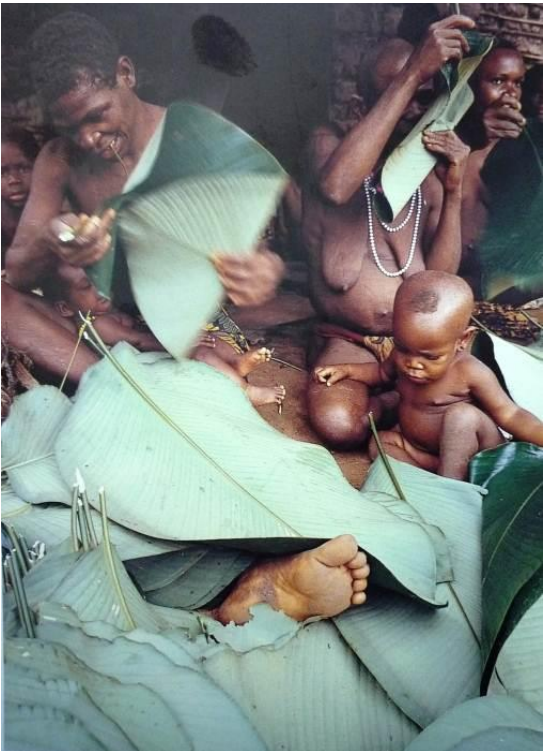

Gambar 15. Perempuan Pygmy, Kongo, menjahit dedaunan yang lebar-lebar untuk pelingkup tendanya

Sumber: Hannah, 2002

Sebagai sebuah karya aktivitas para perempuan itu merupakan proses budaya yang menghasilkan produk budaya, sebagai usaha untuk mengatasi alam, memberi makna atas kehidupannya. Rumah tinggal yang prosentase terbesar materialnya dibuat dari tanah liat dan air yang ada disekitarnya seumpamalah sebuah transformasi simbolik dari daging dan darah yang ada pada tubuhnya. Tubuh dan jasad manusia menjadi personifikasi elemen-elemen alam yang akan dimanfaatkan untuk kaumnya.

\section{Merajut dan Menganyam}

"Menganyam, merajut dan menjalin adalah kegiatan-kegiatan mendasar dalam kebudayaan. Telaah etnologis membuktikan bahwa tindakan menganyam dan menenun batang dan ranting pohon dan kemudian kulit binatang untuk menjadi tenda adalah tindakan awal membuat hunian, jauh ketika manusia masih nomad" (Mahatmanto, 1999).

Perkembangan terkini menunjukkan bahwa keahlian teknik masa lalu, tradisional, yang dimiliki oleh para perempuan dalam membangun rumahnya semenjak dulu, kini mulai luruh. Bakat dan ketrampilan perempuan sebagai anugerah alam masih melekat dan dapat ditemui dalam berbagai aktivitas keseharian. Namun demikian kemampuan tersebut tergeser oleh perkembangan teknologi dan dunia lelaki yang semakin menguasai kemampuan membangun. Ketrampilan perempuan dalam mengolah serat, yang kini lebih dikenal sebagai fiber, pada masa lalu merupakan domain perempuan. Ketrampilan tersebut amat luas cakupannya, mulai dari membuat kain untuk dipakai, perkakas rumah, menghias ruangan, hingga membuat tenda sebagai rumah tinggalnya. Semakin hari kebutuhan menjadi semakin beragam hingga domain perempuan tersebut lama kelamaan dilakukan pula oleh para lelaki. Dan pada perkembangannya kini ketrampilan itu tidak lagi khas dilakukan oleh perempuan saja. 


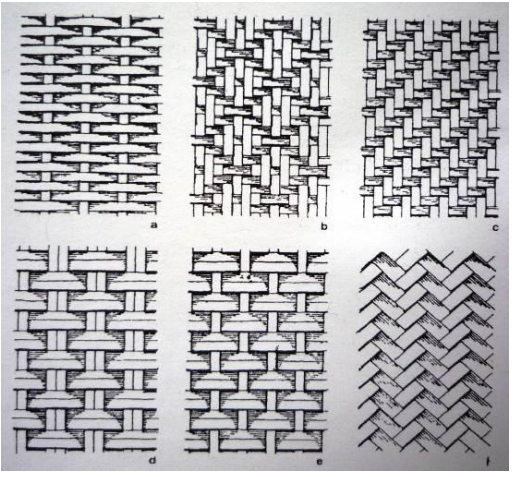

Gambar 16. Anyaman bambu sebagai bahan bangunan

Sumber: Frick, 1997

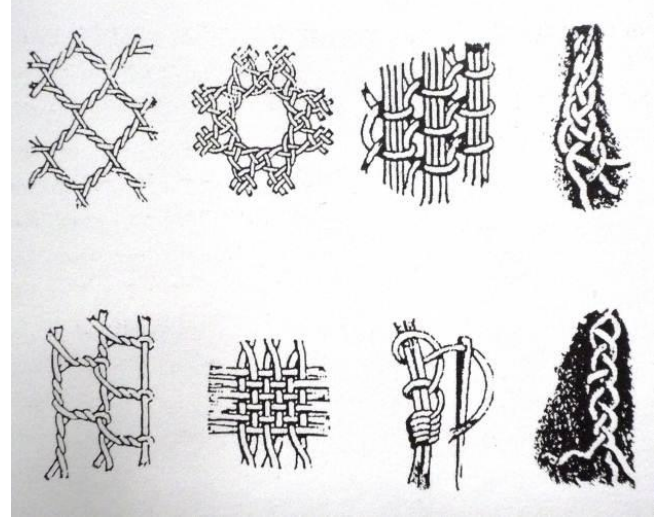

Gambar 17. Rajutan tali untuk berbagai kebutuhan rumah tangga

Sumber: Betsky, 1995

Tindakan menganyam, merajut dan menenun menjadi dasar ketrampilan berarsitektur di Nusantara. Rangkaian bilah bambu, kayu, rotan untuk bidang lebar yang berfungsi sebagai dinding, atap dan penyekat ruang masih banyak dijumpai. Begitu pula dengan raguman ijuk, ilalang, dan bambu menjadi bagian dari kerajinan rakyat yang sebagian digunakan untuk perkakas sedang sebagian lagi menjadi barangbarang seni kriya.

\section{Aplikasi Kekinian}

Ketrampilan perempuan yang kini sudah sangat umum dibuat dan digunakan, tanpa harus membedakan jenis kelamin pembuatnya, juga merambah pada dunia seni kriya dan seni instalasi. Para seniman meman- faatkannya untuk mendesain berbagai gagasan dengan konsep yang lebih kontemporer. Berdasar pada konsep yang sama dengan penciptaan dimasa lalu, pengertian baju sebagai penutup tubuh diindentikkan dengan rumah sebagai pelindung tubuh pula. Kesamaan fungsi antara rumah dan baju yakni sebagai pelindung dari sengatan matahari, cucuran air hujan, berkembang menjadi konsep desain kontemporer yang beraura feminis.

Menggunakan kata 'costume' sebagai titik tolak berkonsep dikembangkanlah costume tersebut menjadi "recycle costume" dan seterusnya. Sebuah konsep penciptaan yang terdiri atas gabungan pemikiran dimasa lalu dengan kondisi nyata masa kini yaitu ketika sampah menjadi masalah lingkungan hidup yang dipandang sangat serius. Penulis menggagaskan recycle costume guna mengetuk perasaan masyarakat agar melakukan penetrasi keprihatinan bersama yang sesungguhnya dapat dikurangi melalui kreativitas yang bertolak dari kearifan masa lalu.

Berjalannya waktu yang menjadi kendaraan budaya untuk berkembang dan berubah, sesungguhnya tidak sertamerta harus mengikis kearifan masa lalu dengan teknologi modern. Seperti dalam kasus pembangunan rumah sejak masa lalu yang menggunakan bahan-bahan alami seperti ranting, kulit binatang, sudah selayaknya dimaknai dengan kemajuan berfikir masa kini. Bertambahnya penduduk dunia serta tuntutan keinginan yang menjadi sangat beragam harus diantisipasi dengan teknologi dan sains yang lebih canggih. Teknologi yang tetap aman bagi manusia dan aman bagi keberlangsungan alam ini. 
Daur ulang perlu dikembangkan lebih lanjut. Penggunaan bahan plastik yang tidak terurai dan tidak terbarukan memberi inspirasi bagi ilmuwan dan seniman untuk memanfaatkan bagi fungsi yang lebih aplikatif hingga pencitraan yang lebih mengarah pada gaya hidup.

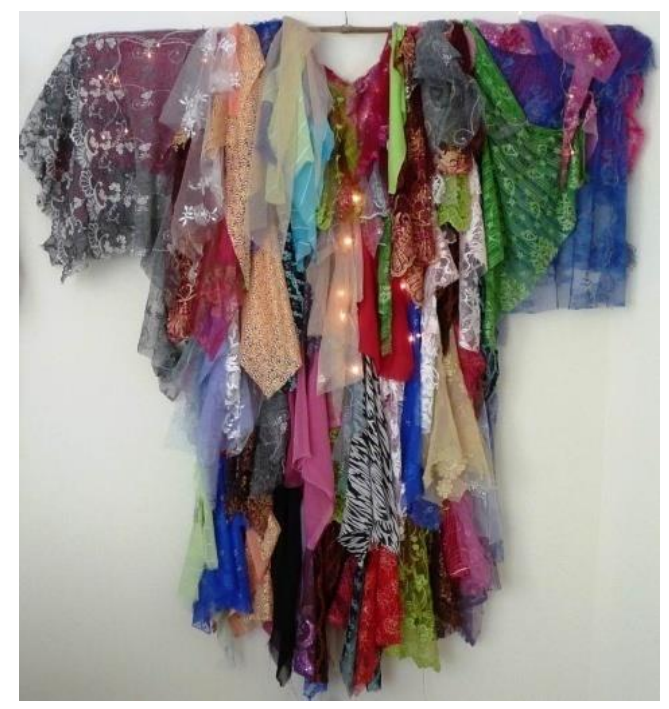

Gambar 18. Recycle Costume, terwujud dengan menyampurkan serat plastik, benang, dan kain perca menjadi komposisi $125 \times 150 \times 15$

Sumber: Dokumentasi Koniherawati, 2008

Istilah 'limbah modern' seperti bangkai peralatan elektronik yang berumur pendek, kemasan makanan dan minuman, sudah dipikirkan proses pendaurulangannya. Namun demikian tak dapat disangkal limbah-limbah tersebutlah yang kini memberikan masalah bagi lingkungan hidup. Dewasa ini masalah sampah plastik sudah merambah pada perdagangan komoditas pertanian. Dahulu mengangkut sayur dari kebun ke pasar dengan keranjang bambu yang dapat dipakai berulang kali. Sekarang pengepakan menggunakan kerancang plastik yang setelah dipakai sekali saja akan berakhir di bak sampah. Hal ini menimbulkan pertanyaan [1] mengapa selalu berbahan plastik [2] bagaimana akhir dari sampah plastik tersebut [3] kemana barang bekas itu pergi dan berakhir.

Aktualisasi konsep masa lalu tentang penggunaan bahan-bahan alami yang pernah dilakukan para ibu untuk penciptaan baju atau rumah sebagai ruang yang melindungi dan memberikan kenyamanan, keamanan secara fungsional merupakan cara berfikir yang handal dan menyeluruh, komprehensif. Pengembangan konsep lama tersebut dapat dilakukan dengan berbagai cara, seperti memberi 'isian' pada sebuah 'kerangka'. Isian merupakan elemen ornamental sekaligus elemen strukturan yang memberi kekuatan dan menjaga stabilitas bentuk. Sebagaimana dalam tradisi membatik kain. Kerangka harus diisi dengan berbagai rupa titik dan garis, yang dalam bahasa Jawa diistilahkan 'isen-isen'. Memberi isian tentu saja agar bentuk tidak kosong serta untuk sebuah pencapaian estetika keindahan (beauty). Isian juga menjadi sebuah cara menuju kestabilitasan keseutuhan (unity), sehingga komposisi menjadi lengkap (completly). Sebagaimana juga dituntut pada sebuah baju, costume, perlu terbentuk oleh tuntutan yang menyeluruh sesuai dengan prinsip dasarnya (design principle).

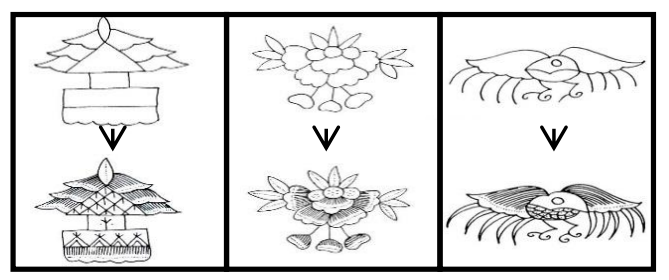

Gambar 19. Isen-isen batik yang melengkapi pola rancangan batik tradisional Sumber: Susanto, 1980 


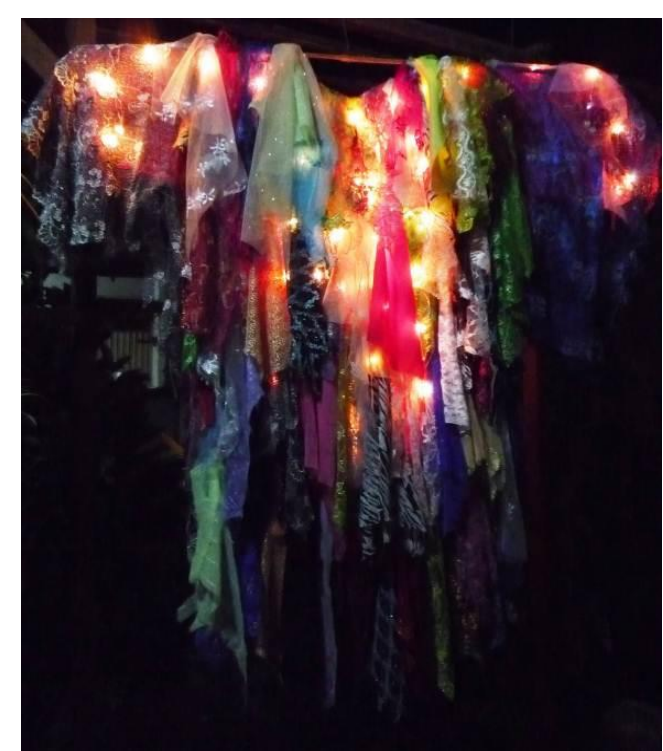

Gambar 20. Pesona rancangan pada siang hari

Sumber: Dokumentasi Koniherawati, 2008

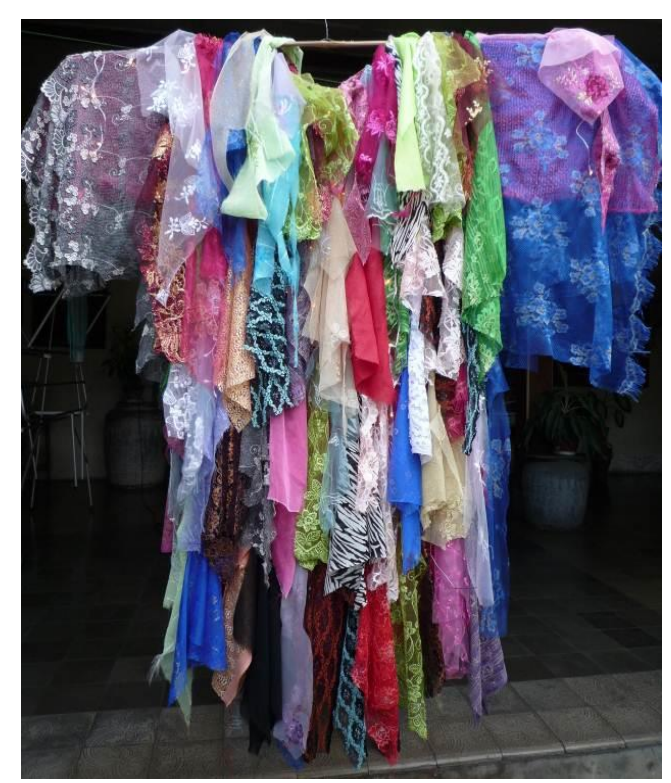

Gambar 21. Pesona rancangan pada malam hari

Sumber: Dokumentasi Koniherawati, 2008

Keragaman bahan semisal kain perca, plastik fiber, serta elemen pendukung lainnya yang lebih kasar dan kokoh menjadi aspek komposisi bentuk yang juga telah dilakukan oleh para perempuan masa lalu dalam lingkungannya yang serba terbatas. Contoh pengolahan komposisi oleh penulis yang menggunakan beragam bahan bekas dengan konsep yang dilakukan para perempuan dimasa lalu yang diberi judul Recycle Costume.

\section{Kesimpulan}

Seni mendirikan bangunan khususnya rumah tinggal tidak terlepas dari kegiatan menyusun satuan demi satuan bahan yang direncanakan melindungi kegiatan penghuni. Rajutan dan hubungan satuan-satuan elemen bangunannya menjadi bagian penting dalam konteks tektonika berasitektur. Arsitektur selalu merangkai keterkaitan relasional antara ruang, tempat, struktur, dan bahan bangunan (space, place, structure and material). Bahwa penciptaan tempat untuk 'ada' si manusia tersebut memerlukan penegasan teritori ruang melalui teknik membangun. Sebagaimana pula dalam membuat baju, bahan bangunan menjadi titik tolak dalam proses membangun. Manipulasi bahan oleh alat dan tekniknya tentu akan menghasilkan karya yang bernilai dan khas seduai dengan potensi alam yang menjadi lokasinya. Semisal pada wilayah penghasil bambu akan memiliki teknik pengolahan bambu dengan peralatan yang sesuai, selanjutnya akan membutuhkan tata cara, prosedur, yang memang cocok untuk bambu. Terobosan pada salah satu dari ketiganya akan membuka khasanah yang tidak habis dicari kemungkinan-kemungkinannya yang lebih baru.

Teknik merajut, menganyam, merupakan tektonika pembuatan sambungan, joint, yang harus ada dan terjamin pada kekuatannya juga pada keselarasannya. Dialog berjumpanya bahan-bahan yang berbeda disatukan seperti layaknya perjumpaan yang selalu berlimpah dengan potensi untuk 
berbagai penafsiran. Seperti apa pertemuan berbagai aspek tersebut berlangsung pada akhirnya akan terbentuk sebuah dominasi, saling berpautan keduanya, serta saling jalinjalinan atau saling menolak. Kesemuanya dapat hadir berdasarkan konsep pemikiran yang melatarbelakanginya. Dekorasi dan menghias ruang arsitektur merupakan kegiatan penciptaan keindahan. Pada akhirnya hadirlah keterpesonaan baik secara natural maupun secara kultural, adat, yang membenamkan kita pada suasana hal indah itu. Dalam menghayati keindahan akan menyadarkan bahwa kelumrahan telah dilampaui, sebagaimana penciptaan yang sederhana maupun yang rumit dapat menggiring pemerhati pada keindahan yang mengungkap kebenaran. Kebenaran tentang bagaimana sebuah karya arsitektur itu dibangun, dirangkai, serta bagaimana bahanbahan yang menjadi elemennya berbicara seperti apa adanya, serta saling berdialog satu dengan yang lain.

\section{Daftar Pustaka}

Betsky, A. (1995). Building sex. New York: William Morron.

Frick, H. (1997). Pola struktural dan teknik bangunan di Indonesia. Jogjakarta: Kanisius.

Hannah, GG. (2002). Elemen of design. New York: Princeton Architectural Press.

Laffon, C. (2004). A home in the world: House and culture. New York: Harry N Abrams.

Mahatmanto.(1989). The tectonic architecture of $Y B$ Mangunwijaya. Jogjakarta: Cemeti Art Gallery.

Rupp, W., dkk. (1989). Construction materials for interior design. New York: Library of Design.
Susanto, SK S. (1980). Seni kerajinan batik Indonesia. Jakarta: Balai Penelitian Batik dan Kerajinan. 